\title{
Land grabbing within a protected area: The experience of local communities with conservation and forestry activities in Los Esteros del Iberá, Argentina
}

\author{
Nienke Busscher ${ }^{\mathrm{a}, \mathrm{b}, *}$, Constanza Parra ${ }^{\mathrm{b}}$, Frank Vanclay ${ }^{\mathrm{a}}$ \\ a University of Groningen, Faculty of Spatial Sciences, PO Box 800, 9700 AV Groningen, The Netherlands \\ ${ }^{\mathrm{b}} \mathrm{KU}$ Leuven - University of Leuven, Department of Earth and Environmental Sciences, Division of Geography and Tourism, P.O. Box 2409, 3001 Leuven, Belgium
}

\section{A R T I C L E I N F O}

\section{Keywords:}

Green grabbing

Extractivism

Neoliberal conservation

Environmental justice

Private protected areas

Political ecology

\begin{abstract}
A B S T R A C T
Protected areas are increasingly being created, managed and owned by private actors, resulting in land grabs that are often at the expense of local control, livelihoods and biodiversity. Changes in land ownership and land use lead to new governance arrangements, which are full of paradoxes, alter ownership responsibilities, and create clashes of perspectives over how nature should be valued and utilised. Conversely, the presence of new actors potentially also brings about socio-environmental awareness and can open-up arenas for dialogue and multi-level collaboration. Using qualitative research methods, we considered two case studies in the protected area, Los Esteros del Iberá, in the north-east of Argentina: the Harvard Management Company's investments in industrial tree plantations; and the conservation project of Douglas Tompkins (i.e. the Conservation Land Trust). Their activities have increased the complexity of socio-political dynamics in the region, leading to contradictions and conflicts, as well as to a strengthened commitment to manage the Iberá region better. Nevertheless, local communities perceived little difference between green grabbing and land grabbing, with all land transfers increasing inequality.
\end{abstract}

\section{Introduction}

Land grabbing changes patterns of land ownership and land use, and fosters new modes of land regulation and governance (Brent, 2015). The exploitation of land and land-based resources by companies also generates socio-environmental conflict, inequality and environmental degradation (de Schutter, 2011). The implications of land grabbing are diverse; in many cases, conflict over land brings about the further political marginalization of the groups of people living nearby (Gerber et al., 2009; Vanclay, 2017a). However, in some cases, land grabbing may create opportunities for people to benefit from the arrival of new actors and capital (Hall et al., 2015). In contrast to the typical conception of land grabs - i.e. the large-scale commercial production of agricultural commodities (Borras et al., 2012a) - land is also being consumed by an increasing array of private conservation initiatives (Igoe and Brockington, 2007). Protected areas and other areas of high ecological value have become vulnerable to land grabbing in several ways, including: by a policy discourse that promotes neoliberal conservation; the increasing demand for ecotourism; the increasing power of big international (environmental) NGOs (BINGOs); and the openingup of local land markets (Büscher et al., 2012; Corson et al., 2013; Igoe and Brockington, 2007; Holmes, 2014a; Zoomers, 2010). These neoliberal conservation initiatives are full of controversy (Fairhead et al., 2012; Vanclay, 2017a).

The entry of new actors in local land markets and the accompanying changes in control over land alter power relationships and can be seen as an expression of the shift from government to governance (Corson and MacDonald, 2012). Drawing on Parra (2010), governance can be defined as the system of regulation involving the interactions between and within a wide range of actors (individuals, institutions, NGOs, companies) at different territorial levels and the socio-institutional arrangements in which they participate. Governance is a multidimensional concept that implies the constant renegotiation, restructuring and readjustment of the various roles and responsibilities of governments, civil society and the market (Castree, 2010; Corson and MacDonald, 2012; Swyngedouw, 2005).

Changes in governance can be manifested in various ways, and the impacts of these changes have been interpreted, perceived and analysed from different perspectives. On the one hand, scholars such as Eden (2009:383) state that the passage from government to governance can entail a "more proactive, preventative and socially relevant decisionmaking" and can imply a change "from closed debates and state-led, reactive and technocratic decision-making to more open, stakeholderled debates in a civil society mode". From this perspective, the

\footnotetext{
* Corresponding author at: University of Groningen, Faculty of Spatial Sciences, PO Box 800, 9700 AV Groningen, The Netherlands.

E-mail addresses: n.a.busscher@rug.nl (N. Busscher), constanza.parra@kuleuven.be (C. Parra), frank.vanclay@rug.nl (F. Vanclay).
} 
diversification of actors brings opportunities to open-up decisionmaking thus empowering citizens (Swyngedouw, 2005). On the other hand, this transformation can be interpreted as the withdrawal or erosion of the state from its environmental regulation and social responsibilities (Fairhead et al., 2012; Klooster, 2010; Swyngedouw, 2005). The growing role of markets and the private sector in biodiversity conservation now constitutes one of the key issues in the governance of the natural environment (Corson and MacDonald, 2012; Klooster, 2010; Zammit, 2013).

The empirical focus of this paper is land grabbing in and around the protected area, Los Esteros del Iberá (henceforth Iberá), which is located in the Province of Corrientes in the north-east of Argentina. The factors that affect governance dynamics in this region include the growing presence of private actors, increasing commodity production under green pretexts, and private conservation initiatives. We examine two cases of land grabbing in this protected area. One case focuses on commodity production, specifically the industrial tree plantations of the Harvard Management Company (HMC), the endowment management fund of Harvard University. The other case is the land acquisition activities in Argentina of the late multi-millionaire, Douglas Tompkins, who through the Conservation Land Trust (CLT) bought large tracts of land in Iberá, primarily for conservation purposes. Both cases reveal the social and environmental issues in the ongoing discussion associated with land of high ecological value being flogged-off to foreigners (Corson and MacDonald, 2012; Fairhead et al., 2012; Lunstrum et al., 2016).

Our two cases of land grabbing can also be considered as 'green grabbing' (Fairhead et al., 2012; Messerli et al., 2013). Our preferred definition of land grabbing is: "the capturing of control of relatively vast tracts of land and other natural resources through a variety of mechanisms and forms involving large-scale capital that often shifts resource use to that of extraction, whether for international or domestic purposes" (Borras et al., 2012a:405). The focus on control in this definition means that local people do not necessarily have to be expelled from the land, but rather that their resource access is lost or diminished (Hall et al., 2015). Green grabbing, a term first used by Vidal (2008), primarily concerns land acquisition for environmental purposes, such as biodiversity conservation, national parks, carbon sequestration, biofuel production, ecosystem services, ecotourism, or offsets (Fairhead et al., 2012; Vanclay, 2017a). Green grabbing adds a new dimension to the debate over land grabbing in that environmental reasons are used to justify the acquisition of land and associated resources (Corson et al., 2013; Fairhead et al., 2012). A sense of environmental crisis in various forms, e.g. resource scarcity, biodiversity loss, climate change, is also promoted to legitimate green grabbing (Castree, 2010; Corson, 2011; Fairhead et al., 2012; Igoe and Brockington, 2007). Green grabbing causes the displacement of people creating inequality, social impacts and human rights impacts (Brockington and Igoe, 2006; Fairhead et al., 2012; Lunstrum et al., 2016; Vanclay, 2017a, 2017b).

Drawing on the two case studies in Iberá, our aim is to discuss the characteristics of the governance of land grabbing in and around protected areas. Protected areas are defined as designated spaces that are managed to achieve the objectives of preserving natural qualities, biodiversity, and/or cultural heritage (Parra and Moulaert, 2016). In their creation and ongoing operation, protected areas can have detrimental impacts on local people (Brockington et al., 2008; Büscher and Fletcher, 2015; Holmes, 2014b; Vanclay, 2017a,b). By zooming in on the most important governance dynamics, we explore how land grabs and subsequent governance changes provoke socio-political development as well as conflict. Our focus on land governance also helps to understand the mechanisms, practices and processes that lead to inequality.

With a growing diversity of forms of conservation, the governance of protected areas has become increasingly complex. Therefore, examining the roles, responsibilities, activities and interests of the different key actors is even more important (Cavanagh and Benjaminsen,
2014; Hanna et al., 2008; Oliveira and Hecht, 2016). An analysis of governance is useful to gain a better understanding of land grabbing from the positions and perspectives of the full range of actors. We suggest that the multi-level governance character of land grabbing potentially can lead to positive as well as negative outcomes. Nevertheless, the negative issues arising from land grabbing are frequently difficult to address because of local contextual factors. Moreover, we show that the negative implications of land grabbing are experienced far beyond the boundaries of the land investment itself.

\section{Land grabbing and its characteristics}

Contemporary research suggests that understanding of the drivers and impacts of land grabbing is still developing (Hall et al., 2015; Temper, 2018). Initially, the literature on land grabbing focussed on local resistance, displacement and the privatisation of land (the new enclosures) (Borras et al., 2012a, 2012b, 2013; Holmén, 2015), whereas now land grabbing research goes further, for example, new insights have revealed that local people are not always against land grabbing (Hall et al., 2015; Holmén, 2015). In certain cases, local people, and women in particular, may actively seek to benefit from the jobs that might flow from land grabbing (Hall et al., 2015). In other situations, local people engage in negotiation or struggle to improve the terms and conditions under which land grabbing occurs and the outcomes that follow (Hanna et al., 2014; Hall et al., 2015). Their actions are directed to various actors, including the state, investors, the wider public and to others in the local community. In this struggle, tensions can occur between different groups of local people (Borras et al., 2013, 2016). Sometimes, people decide not to resist but to adapt to the negative situation brought about by land grabbing. Recent insights show that land grabbing creates unintended as well as intended, unexpected and expected social impacts and political dynamics (Hall et al., 2015; Holmes, 2014a), which was also evident in our research as we discuss below.

Based on research in Sub-Saharan Africa, Holmén (2015) identified four reasons explaining why land grabbing occurs: (1) there is a prejudice favouring large-scale development over local farming; (2) governments have been keen to attract land investments and foreign money, for example to develop much-needed infrastructure; (3) corruption and a lack of capacity with government exists in many forms, including in weak land policies; and (4) there has been misguided foreign advice. We consider that these reasons play a significant role universally, including in Latin America. With many different contexts in the world, the specificities of how land grabbing plays out varies from place to place (Borras et al., 2012b), but there are also generalities (Edelman et al., 2013). For example, in the Latin American context, Grajales (2011) emphasised the use of violence in Colombia. Costantino (2015) suggested that there were relatively high returns on land investments in Argentina and the myth of the relative abundance of land.

While land grabbing might be a necessary evil for countries to produce commodities, keep economies running, gain foreign currency to pay off debts, or to develop economically (Baird, 2011; Cotula et al., 2009; Fairhead et al., 2012), the negative effects of land grabbing on local people are extensive (Fairhead et al., 2012; Messerli et al., 2013). From a social perspective, the established impacts of land grabbing include violation of human rights, ignoring customary land rights, livelihood changes, forced evictions, and the criminalization of local people as they take action to protect their interests (Brent, 2015; Hanna et al., 2016a; Holmes, 2014a; Messerli et al., 2013; Vanclay, 2017b). The main negative consequences from an environmental perspective are biodiversity loss, ecosystem changes, water shortages, and pollution (Svampa and Viale, 2014). Land grabbing can lead to loss of income and job opportunities, reduced possibilities to own land in the future, increased land prices, and increased inequality with land ownership shifting into the hands of elites (Costantino, 2016; Davis et al., 2014). 


\section{The governance dynamics of land grabbing in protected areas}

Land grabs have introduced many changes to institutional arrangements and power dynamics (Borras et al., 2013; Corson, 2011; Margulis et al., 2013). A wide range of actors in diverse institutional settings at different spatial levels are now influencing, mediating and negotiating territory (Brent, 2015; Margulis et al., 2013). Manifestations of new forms of land governance include the policies, standards and guidelines of global institutions (e.g. FAO, 2012), the various certification schemes of industry bodies (e.g. FSC, 2015), and what is becoming known as good international industry practice (GIIP). Although certification schemes arguably have the potential to improve environmental and social governance (Dare et al., 2011; Eden, 2009; Fortin and Richardson, 2013), they have been criticized for prioritizing economic over social and environmental issues, and for not protecting informal land users (Cook and Swyngedouw, 2012; Fortin and Richardson, 2013).

New governance modes create opportunities for new forms of political pressure, which local resistance groups use to advance their causes (Hanna et al., 2016a, 2016b). With the roles and responsibilities of the state and other actors being continuously negotiated and disputed, new modes of action for local people are created, as are new ways by which powerful actors can impose their agendas (Hall et al., 2015). Often, the interests of the local community are not heeded and thus they will likely consider different strategies, often at different levels, in an attempt to have their concerns addressed (Moulaert et al., 2014), a phenomenon Swyngedouw (2005) called 'scale-jumping'.

Various systems of conservation can be observed, arising from the increasingly-varied strategies for protecting nature (Büscher et al., 2012; Büscher and Fletcher, 2015; Hanna et al., 2008; Igoe and Brockington, 2007; Parra, 2010; UN, 1992). The concept of neoliberal conservation is used to explain this diversification. Neoliberal conservation refers to the introduction of market mechanisms to the field of nature conservation. This leads to stakeholders other than the state, i.e. private actors, having an active role in protecting nature, as well as to the opening-up of opportunities to derive profit from conservation efforts (Igoe and Brockington, 2007). Neoliberal conservation is undertaken in different forms, by different actors, at different levels (Corson, 2011). It is sometimes suggested that local communities can benefit from these new conservation modes, e.g. in terms of ability to establish or join conservation-related businesses (Igoe and Brockington, 2007; Zammit, 2013). However, land grabbing for conservation by private actors can have many negative impacts, which are extensively discussed in the literature on neoliberal conservation and green grabbing (Holmes and Cavanagh, 2016; Jones et al., 2017; Vanclay, 2017a).

Allegedly neoliberal conservation is more "democratic, efficient, equitable, and profitable" (Igoe and Brockington, 2007:433). In practice, however, many contradictions can be observed (Büscher and Fletcher, 2015; Castree and Henderson, 2014; Cundill et al., 2013). On the positive side, diverse civil society engagement in nature conservation programs can create new spaces and institutions to protect nature (Stolton and Dudley, 2010). Protected areas are increasingly being established and run by various forms of non-governmental organisations (NGOs) and not-for-profit organisations (NFPs), often funded by donations (Corson, 2011; Vidal, 2008). Moreover, the growing pressure on governments from these actors may lead to a renewed state interest in conservation activities and the expansion of protected areas (Büscher et al., 2012; Holmes, 2014a).

More critically, however, contemporary conservation programs may facilitate a further withdrawal of the state from the protection of nature given that other actors are taking over this task (Corson, 2011). Private actors operating in conservation areas have frequently been criticized for utilizing nature for commodity production, or 'fictitious conservation' (Büscher and Fletcher, 2015). Their productive uses may harm biodiversity or local people, especially where limited regulation may require, allow, or at least not prevent environmental degradation
(Büscher and Fletcher, 2015; Castree and Henderson, 2014; Holmes, 2014a; Igoe and Brockington, 2007).

The rhetoric behind conservation schemes tends to be characterised by entwined, overlapping and complex reasonings that make their aims and determination of success difficult to assess. This can be illustrated by an example from Oliveira and Hecht (2016), who explained that some environmental NGOs in Brazil advocate for the intensification of harmful production practices (that they formerly resisted) in the interests of 'land sparing'. These NGOs argued that intensification of some land has the potential to reduce the extent of conversion of other land (potentially of high ecological value) to soy production (thus saving or sparing it). The use of catch-phrases - e.g. save the wildlife, restore the global environment, feed the world, stop climate change - not only reveals confusion about the roles and responsibilities of the various actors, but is frequently intended to obfuscate (Cavanagh and Benjaminsen, 2014; Fleming et al., 2014; Oliveira and Hecht, 2016; Rocheleau, 2015). The extent of the diversity of forms of nature conservation raises questions about the meaning, purpose and governance of protected areas and about the exact roles and responsibilities of the state, the market and civil society (Holmes, 2014b; Minteer and Pyne, 2015).

Despite the potential benefits new modes of governance bring, the way governance actually plays out in practice has several unfulfilled promises, which Swyngedouw (2005) suggests are: (1) a more democratic society - whereas in reality not every group participates or benefits equally; (2) greater opportunities for involvement - but the hegemonic influence of state and market power persist; and (3) greater transparency - but there is blurred accountability regarding who is responsible for the various tasks and roles. Governance dynamics in protected areas are complex and are constantly being negotiated, as we discuss below in the context of Iberá, Argentina.

\section{Methodology for the case studies}

Our research was conducted in the region of Los Esteros del Iberá in the Province of Corrientes in Argentina (see Fig. 1). Iberá has unique ecological and hydrological qualities that facilitate commodity production and attract land investors and conservationists alike. Over the last ten years or so, two large-scale land owners in Iberá have been the Harvard Management Company (HMC), which invested in industrial tree plantations in the protected area and surrounding buffer zone, and the Conservation Land Trust (CLT), which was founded by the conservationist, Douglas Tompkins.

The lead author carried out fieldwork in Corrientes in 2014 and 2015. The research methods included document analysis, in-depth interviews and participant observation. Key interviewees within government institutions, companies, NGOs, as well as prominent individuals in local communities were identified and approached. A process of snowball sampling was used to ensure all key people were interviewed. Key staff of HMC and CLT were also interviewed as well as several people from local impacted communities. A total of 42 individuals plus 4 rural families were interviewed. The interviews covered a wide range of topics related to land politics in Argentina, the investments of HMC and/or CLT, and community concerns about these investments. Informed consent was obtained for all interviews, and other ethical research considerations were observed (Vanclay et al., 2013). Interviews were recorded when permission was given, however most participants preferred that the interview not be recorded. Although a list of key topics to be covered was determined prior to each interview, the interviews tended to be of an open conversation format. The setting of most interviews was informal. For example, some interviews were conducted while the interviewer participated in family or work activities of the interviewee. Where possible and appropriate, triangulation was done to validate information, especially of critical or controversial issues. 


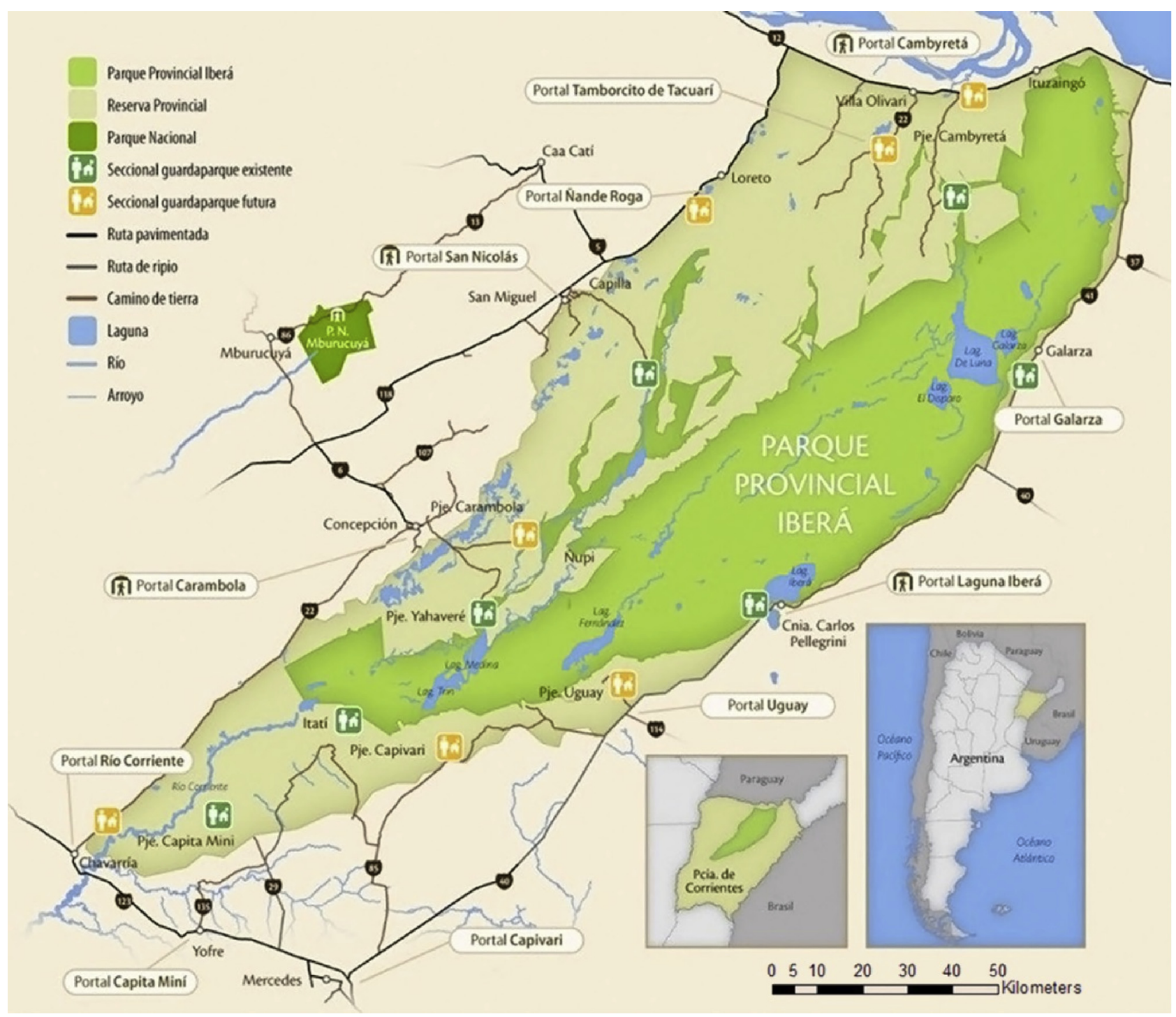

Fig. 1. Location of Los Esteros del Iberá.

(Note that in late 2016 the provincial park became part of a new national park).

Source: Proyecto Iberá (2016) (used with permission)

\section{Background information about land governance and extractivism in Iberá}

Argentina has a federal government system, combining provincial and national regulations, with each province having its own idiocrasies. For the past decade or so, the provincial government of Corrientes has not been politically aligned with the national government. The provincial government argues that, because of this, it has received far less discretionary funding than other provinces in north-east Argentina (Gobierno Provincial, 2015). Along with other historical and structural factors, this has contributed to Corrientes being one of the poorest provinces in Argentina (World Bank, 2010).

Corrientes is characterized by a small number of elites owning large tracts of land, and having one of the highest percentages of foreign land ownership in Argentina (Ministerio de Justicia y Derechos Humanos, 2017; Slutzky, 2014). Surface and ground water resources are abundant, with extensive wetlands and two major rivers flowing through the province. Corrientes also hosts part of the Guaraní Aquifer, one of the world's largest reserves of fresh water (Tujcheider et al., 2007). There is structural social deprivation, exacerbated by limited employment opportunities. The factors that contribute to the persistence of social deprivation include the poor quality of infrastructure (e.g. electricity, water distribution, roads, drainage), high unemployment rates, low education levels and inadequate healthcare (Neiff, 2004; Slutzky, 2014; World Bank, 2010).

Argentina is known for its agriculture (especially soy) and extractive industries, and for the export of unprocessed raw materials (Gudynas et al., 2009; Oliveira and Hecht, 2016; Svampa and Viale, 2014). Investment in agricultural industries has increased in recent decades as well as land acquisition for conservation purposes (see Murmis and Murmis, 2012; Veltmeyer and Petras, 2014). This increase in land investment has had many consequences, notably the displacement of people, insecure tenure, inflation of land prices, and conflict (Brent, 2015; Murmis and Murmis, 2012).

One of the dimensions of the land grabbing process is that many smallholders do not possess formal land titles. Smallholders without formal title typically live either on land owned by a formal land owner who is not actively using the land, or on land owned by the state (Costantino, 2015; Jara and Paz, 2013). Even though the Argentine Civil Code provided a mechanism for informal owners to gain formal land titles when they have lived on the same piece of land for over 20 years, people have struggled to exercise this right (Goldfarb and van der 
Table 1

Foreign investments in Iberá and its buffer zone.

Source: author compilation based on Aranda (2015); Hábitat y Desarrollo (2014); CLT (2016) and Ruta de Arroz (2011)

\begin{tabular}{lll}
\hline Name of investor & $\begin{array}{l}\text { Area owned (approx) } \\
\text { (hectares) }\end{array}$ & Main purpose \\
\hline $\begin{array}{l}\text { Gilberte Yvonne Andrée Lovisi } \\
\text { de Beaux }\end{array}$ & 51,000 & rice production \\
$\begin{array}{l}\text { George Soros } \\
\text { Harvard Management Company }\end{array}$ & $\begin{array}{l}76,500 \\
88,000\end{array}$ & $\begin{array}{l}\text { rice production } \\
\text { industrial tree } \\
\text { plantations } \\
\text { conservation }\end{array}$ \\
$\begin{array}{l}\text { Tompkins/The Conservation } \\
\text { Land Trust }\end{array}$ & 150,000 & \\
\end{tabular}

Haar, 2015; Leguizamón, 2016). Obtaining land titles based on historical land use or customary rights is complicated and prohibitively expensive for informal land users (Brent, 2015). In the past, formal title holders were not particularly worried about communities starting procedures to gain formal land title, because the land was not seen as having much value. Now, with a ready market for land and increased land values, formal land owners are actively selling off or leasing their land to land investors, and are becoming concerned about informal land users claiming rights over land (Jara and Paz, 2013). In some situations, new investors might (unknowingly) encounter people living on the land and who have built up rights to this land, which often results in conflict. The government is also actively selling off land (Costantino, 2015). The lack of formal land title disadvantages local people, especially when there are competing claims over land (Costantino, 2015; Messerli et al., 2013). It also makes the land grabbing process complex, and arguably increases the social impacts that are experienced.

The factors facilitating land grabbing in Argentina are similar to those identified by Holmén (2015) regarding Sub-Saharan Africa discussed earlier. In Argentina, there is a strong prejudice by companies and government agencies against rural people because of differing cosmovisions, values, and levels of land attachment (Bidaseca et al., 2013). Moreover, smallholders are not perceived as contributing to economic progress, leading to the view that rural areas are in need of modernization, which is believed to come with foreign land investment. Argentina needs foreign direct investment to pay off its very large external debt (Bidaseca et al., 2013; Gudynas et al., 2009). Indebted countries are likely to put nature up for sale (Fairhead et al., 2012). Corruption is also a factor in Argentina, and many non-transparent land transfers have been facilitated with the inappropriate collaboration of notaries or land registry staff (Goldfarb and van der Haar, 2015). Regarding misdirected foreign advice, the structural adjustment programmes promoted by the World Bank have led to much protest and social harm (Brent, 2015; Harvey, 2005). All up, these four factors have led to an enabling setting for land grabs in rural, urban and protected areas of Argentina.

Some specific characteristics of land grabbing in Argentina include the active role of the state in supporting foreign investors to gain land (Costantino, 2015; Jara and Paz, 2013). This includes lowering entry barriers, selling-off public land, and authorizing deforestation. Some economic characteristics that provided an incentive for foreign investors to invest in Argentina were the profitability of agricultural exports due to the devaluation of the peso. In addition, low interest rates in Argentina and other countries like the United States also stimulated land investments (see Costantino, 2015 for an in-depth analysis of economic factors influencing the land market).

The protected area, Los Esteros del Iberá, was created in 1983 by the Province of Corrientes and is now the biggest nature reserve in Argentina with approximately 1.3 million hectares (Provincia de Corrientes, 2014). Iberá has a mix of wetland and grassland ecosystems. The abundance of water and nutrients have led to it being rich in biodiversity (Silva et al., 2005). Up until 2016 (when the Parque
Provincial Iberá was converted into the Iberá National Park), Iberá had two parts, the Reserva Natural Iberá and the Parque Provincial Iberá (see Fig. 1). In the Reserva Natural Iberá $(818,000$ ha), private land owners could undertake productive activities providing they adhered to guidelines like avoiding biodiversity loss and protecting significant habitats (Gobierno Provincial Corrientes, 2015). The water, favourable climate and high rainfall attracted investors who used the area for a range of purposes including tree plantations, rice production, grazing, and conservation projects. The Parque Provincial Iberá (482,000 ha) was a protected conservation zone dedicated to preserving native species and to providing a high quality tourist experience (Gobierno Provincial Corrientes, 2015).

Despite its protected status, various socio-environmental conflicts have occurred and threats to biodiversity protection exist, including: the construction of illegal drainage channels and embankments; harmful practices such as the application of chemicals and fertilizers; the spread of invasive exotic plant and animal species; and illegal fishing and hunting (Boletín de los Esteros, 2010). Controversial land acquisitions are associated with various multi-millionaires, including George Soros, Gilberte Yvonne Andrée Lovisi de Beaux (a French banking magnate), and the late Douglas Tompkins (Aranda, 2015; Cultural Survival, 2014; Pittaro, 2011; Ruta de Arroz, 2011) (see Table 1). It is claimed by some that their resource use is not consistent with the special characteristics of the region's sensitive ecosystems (Boletín de los Esteros, 2010; Loiselle et al., 2004; Saverin, 2014).

The communities living in and around Iberá are diverse. Most communities descend from the Guaraní Indigenous peoples. Families tend to be large with up to 12 children. They engage in a wide variety of livelihood activities including hunting, fishing and subsistence farming. Local employment options once included working on cattle ranches, although this has now largely been replaced by the forestry industry. Government social welfare assistance is an important source of income. The vast majority of people do not possess land titles. Local communities use and drink water from the lagoons as there is no town water supply system. They have experienced many changes with the arrival of investors (see Neiff, 2004).

The policies implemented by the provincial government increasingly promote neoliberal conservation practices. Different trends indicate this shift from conventional to neoliberal conservation in Iberá. The province implemented a twofold strategy of increasing biodiversity while making money out tourism; and increasing access to the park (Gobierno Provincial Corrientes, 2015). There is an increasing focus on ecotourism. There is also an increasing number of conservancies, i.e. private properties dedicated to biodiversity protection or ecotourism (Gobierno Provincial Corrientes, 2015). Finally, environmental NGOs are having greater influence on the management of Iberá.

\section{Land grabs in Iberá: Harvard Management Company's tree plantations}

HMC is a $\$ 37$ billion investment management fund associated with Harvard University (Harvard Management Company, 2018). HMC's investment portfolio is broadly based, but includes real estate and tree plantations. Since 2005, HMC has invested in plantation forestry in Argentina and elsewhere, and its natural resources portfolio was a key feature of its philosophy of sustainable investment. In 2015, HMC owned approximately 88,000 ha in the buffer zone of the Iberá park. However, HMC experienced ongoing controversy about its forestry operations and recent poor investment returns, which in late 2016 led to changes in leadership and to its corporate and investment strategy reducing commitment to its natural resources portfolio (Harvard Management Company, 2018).

Revenue generated from HMC's investments is used to support Harvard's academic programs, provide financial aid for students, and fund research. HMC's philosophy is to ensure the financial sustainability of the fund so that subsequent generations can be supported into 
the future, as well as demonstrating a commitment to sustainable investment, specifically to the six Principles for Responsible Investment (PRI, 2016). Although minor in terms of HMC's total financial position, as at 2015, HMC had planted over 100 million trees and owned approximately 242,800 ha of land worldwide, about half of which was reserved for conservation (Hoyle, 2014). Before the change in corporate strategy in late 2016, the HMC story was ostensibly 'green' in that it presented itself as being in the business of sustainable investment, committed to the sound management of environmental, social and governance factors, and in bringing benefits to local people.

HMC's plantations in Corrientes were managed by two subsidiaries it acquired, Empresas Verdes Argentina Sociedad Anónima (EVASA), and Las Misiones. HMC had a minority holding in these companies from 2007, gaining full ownership in 2010. The operations of EVASA and Las Misiones created some 200 permanent jobs. All HMC tree plantations in Iberá have been FSC certified since 2014 (Business Wire, 2014). Nevertheless, several problems have been noted by local people (discussed further below).

The area surrounding HMC's plantations in Iberá is diverse, with small settlements, villages and towns. They have all been affected by HMC's plantations, albeit in different ways, especially as a result of land acquisition by EVASA and Las Misiones. They are also affected by the increasing demand for land by other actors. Our research participants expressed concern about how the expansion of tree plantations has led to an uncertain land tenure situation. This concern was taken up by the local NGO, Unión Campesina, whose mission is to improve the life of poor people in rural areas of Corrientes. In response to the fear of further plantation expansion that is held by most villagers, for several years Unión Campesina pressured the provincial government to formalize informal land holdings, which was achieved in 2014. As a precaution against land grabbing, one condition associated with being granted formal land title is a prohibition on selling the land for ten years after formal title is given (see also Partido Comunista Revolucionario de la Argentina, 2014). Another condition is that the land can never be used for industrial forestry. However, people who have not sought or been able to secure formal title have continued to be vulnerable to land speculators. Some interviewees described being visited by people working on behalf of forestry companies in the region (not EVASA and Las Misiones) who sought to induce them to leave their land. An implication of this would be, should they leave their land, this would potentially invalidate their ability to later claim formal title. Encounters with forestry company representatives were generally distressing to local people.

There were also controversies around the way EVASA and Las Misiones acquired land. We were told HMC had gained possession of public land. Although the conversion of public land to private ownership is common in Argentina (Sili and Soumoulou, 2011), it is controversial because normally there are people and communities living on public land (Bidaseca et al., 2013). Therefore, the question arises as to what happened to the people previously living on the land acquired by HMC's subsidiaries. Our sources suggest that there were people previously living on this land and that a large number of families were displaced. Even though there are no publicly-available records of compensation or resettlement arrangements, we understand that people were induced to leave voluntarily and that adequate compensation was provided. In our interviews with local people, this was generally confirmed, but it was noted that there was dissatisfaction with the level of compensation and the process used to gain land. One interviewee mentioned that the people who left no longer live in rural areas and therefore are in poverty because they lack the ability to engage in subsistence activities and have been unable to establish other livelihoods. The lack of land title and uncertainty about who has land rights has exacerbated the conflict around the competing claims over land. Although the provincial government was keen to sell land to raise revenue, local people considered they did not benefit from land sales and they were concerned about corruption. They thought the government had a vested interest in not acknowledging the land rights of people living on public land.

The expansion of plantations in Corrientes has led to wider social transformation, as it required a change in the amount and nature in the available work from that associated with cattle ranching to forestry. In general, this change in work activities was not favoured by local people. With the large number of heavy trucks transporting logs and equipment, there has been a deterioration and diminished accessibility of roads, which were already badly maintained. Because of increased traffic, there has been an increase in dust, risk of accidents, and other health and safety issues. Although these issues are not solved, EVASA made improvements to the road following complaints from villagers (Oakland Institute, 2013). Finally, people now living close to plantations have lost their sense of place and aesthetic enjoyment of the landscape. Instead of open spaces, people are now surrounded by a wall of trees. On the environmental side, there has been a reduction in water availability because of the high water consumption of plantation trees. The lowering of the watertable has affected people's access to water, and influences their ability to cultivate food. One interviewee said: "the plantations have been appalling for us ... we used to have a bucket well that was only $2.5 \mathrm{~m}$ deep ... nowadays we need a shaft more than $10 \mathrm{~m}$ deep to get water".

A controversial point about HMC was its FSC certification, especially because one of its plantations was in an area of high conservation value. Industrial forestry operations in the Iberá reserve potentially reduce biodiversity and facilitate the dispersion outside of plantations of species like pine and eucalyptus (Boletín de los Esteros, 2010; Gerber, 2011; Overbeek et al., 2012). Slash pine (Pinus elliottii) is particularly prone to spreading (Zalba, 2010), thus is a major threat to the protected conservation zone. Acknowledging this, staff of EVASA and Las Misiones said in an interview that HMC will not plant slash pine in the future. Another controversial point about the FSC certification was the extent of local opposition to the plantations, suggesting that HMC was not meeting all FSC principles, especially with regard to treatment of local communities.

Despite these controversies, in our interviews local people said that EVASA and Las Misiones were companies with relatively good labour conditions and were considered to be managing the plantations more responsibly than the local forestry companies. Perhaps this relatively good reputation was largely due to the malpractice of other companies operating in Corrientes. Most local companies failed to provide protective clothing for their employees, had inadequate or no fire prevention in place, and a general neglect of the plantations could be observed. However, from what was said in interviews, it seemed that HMC and/or its subsidiaries were potentially failing to ensure their subcontractors maintained full respect for the rights of their workers.

\section{Land grabs in Iberá: the conservation projects of Douglas Tompkins}

Douglas Tompkins (1943-2015) accumulated significant capital and publicity from the success of the outdoor brand, The North Face, and clothing company, Esprit. He and Kristine Tompkins (nee McDivitt), whom he married in 1993, have dedicated much of their time and resources to conservation projects. ${ }^{1}$ Under the umbrella of Tompkins Conservation, they became noted conservationists and philanthropists establishing many reserves via a series of subsidiaries in Chile and Argentina. The Conservation Land Trust (CLT) was originally founded in 1992, with its Argentinean arm formally created in 1998. Starting

\footnotetext{
${ }^{\mathbf{1}}$ For more information on the projects of Douglas and Kris Tompkins see: Our Story, Tompkins Conservation https://www.youtube.com/watch?v= 5sfyGCzqGMc; Douglas Tompkins: Wild Legacy on Vimeo https://vimeo.com/ 172053488 or YouTube https://www.youtube.com/watch?v=2QDnhjkULdM; and Corrientes Becomes Corrientes Again on: http://cltargentina.org/en/cvsc.htm
} 
with the purchase of the cattle ranch, Estancia San Alonso, in 1997, CLT gradually acquired several other properties in Iberá totalling over 150,000 ha at the time of our research in 2015 . The land was being used for a variety of purposes including conservation, tourism, organic agriculture and biodiversity protection (CLT, 2016; Tompkins Conservation, 2017).

The Tompkins were arguably responsible for starting discussions about nature conservation and sustainability in some parts of Latin America. Their not-for-profit organisations - e.g. Foundation for Deep Ecology, Conservacion Patagonica and CLT - have established several private protected areas (Tompkins Conservation, 2017), including the Pumalín and Patagonia Parks in Chile. They were actively involved in the creation of the Impenetrable National Park in Argentina in 2014 by supporting a campaign to pool land donations from individuals, NGOs/ NFPs and companies (Giardinelli, 2015). Arguably with the change in government in Argentina in December 2015, Kris Tompkins announced plans for the phased transfer of CLT-held land in Corrientes to the Argentinean state. A similar arrangement has also been implemented in Chile. The Iberá National Park, which was gazetted in 2016, is the largest national park in Argentina (La Nación, 2015). It includes part of the Los Esteros del Iberá protected area and now covers 700,000 ha (550,000 held by the state, and the 150,000 formerly owned by CLT gradually being transferred to the state). In the conditions associated with the transfer, CLT staff continue to be involved in the administration of the park and retain some influence over acceptable uses of the park (see also Corson, 2011).

Several controversies revolve around Tompkins and their conservation projects in Iberá and elsewhere (Holmes, 2014a). Their presence has produced suspicion and mistrust regarding their intentions. Although the Tompkins always expressed their wish to transfer the land to the Argentinean and Chilean states to create national parks, for countries more used to the exploitation of nature rather than its protection and low levels of trust in the state, the goals of the Tompkins were difficult for local people to comprehend (see El Litoral, 2006a). Irrespective of the intention, a major concern expressed by our interviewees was the fact that a foreigner could obtain such large tracts of land, which they considered affected their sovereignty. People were suspicious of the Tompkins and imagined many fanciful reasons for their presence such as: grabbing water from the Guarani Aquifer; starting a military base; and various other illegal activities. Interviewees and media sources denounced his alleged extraordinary profit making through land sales (see for example La Política Online, 2011). A range of concerns relating to local communities were also mentioned. For example, as a result of a land investment surrounding the Yahaveré community in Iberá, Tompkins was accused of illegally closing a school and, by fencing the land in question, effectively locking-in or enclosing the community (El Diario Digital, 2007; Mi Mercedes, 2007). Tompkins later donated some land back to the Yahaveré community and reopened access roads that were restricted by his land acquisitions (El Litoral, 2006b).

Another controversy concerned the relationship between Tompkins and HMC. Actually, Tompkins originally founded EVASA in 2003 (now owned by HMC). In 2007, Tompkins sold some land to the Global Environment Fund, which later sold it to HMC (Oakland Institute, 2013; Pittaro, 2011). As a result of these transactions, Tompkins is still associated by our interviewees with HMC and erroneously with current ownership of tree plantations in Iberá.

A further concern for local people was the planned reintroduction of the jaguar, which was locally extinct because of excessive hunting. Feelings about the reintroduction were mixed. A small group of people feared the impact of jaguars on livestock, while the majority of people felt a sense of pride in having this emblematic animal restored to Iberá.

\section{Governance dynamics in Los Esteros del Iberá}

There are many factors that need to be taken into consideration when examining the relationship between land grabbing and the governance of protected areas. Iberá is very big and relatively remote. Responsibility for park management is spread across ministries, political territories and institutions. The park has limited resources, and monitoring and ensuring compliance is difficult. Its limited accessibility, inadequate policy framework, and a general lack of capacity and resources contribute to making the interactions between key actors challenging and create ongoing socio-political tension. The limited capacity of states is frequently given as a justification for neoliberal conservation (see Igoe and Brockington, 2007). To understand the characteristics of land grabbing in and around protected areas, and the roles different actors play, the key governance processes in our two cases are discussed below.

\subsection{Socio-environmental conflict over HMC's tree plantations}

The struggle against land grabbing by HMC (in the form of EVASA and Las Misiones) and its forestry operations has connected two groups operating at different spatial scales: the coalition, Responsible Investment at Harvard (Responsible Harvard for short), and the local NGO, Guardianes del Iberá. Responsible Harvard gathers students, alumni, and other Harvard community members who demand more transparent and socially responsible investments from HMC (Oakland Institute, 2013). Guardianes del Iberá (i.e. Guardians of Iberá) is a local action group which advocates for local interests and local sustainability concerns in and around Iberá. Inter alia, it demands stronger regulation of plantations, greater community participation (for example in environmental impact assessments), and better employment conditions for workers.

In 2013, Responsible Harvard started investigating HMC's plantations in Iberá in collaboration with Guardianes del Iberá. In the words of the two students leading the investigation, "we went [to Argentina] because we knew that research on Harvard's land grabs in Mozambique led to badly needed scrutiny of those investments ... and a public spotlight could lead to changes for the better in Argentina" (Bayard and Wohns, 2014, para 5). An independent thinktank, the Oakland Institute (2013), published their report, which stimulated Responsible Harvard to initiate a variety of protest actions, including mounting a worldwide petition hosted by the online campaigning community, Avaaz, and holding an event at Harvard University featuring two people from Guardianes del Iberá who discussed the problems caused by HMC. Arguably influenced by these actions, in 2014 HMC appointed a vice president for sustainable investment and signed the Principles for Responsible Investment (Harvard Gazette, 2014). The Principles for Responsible Investment contribute to the creation of long-term value by integrating environmental, social and governance issues in investment projects (PRI, 2016). HMC's efforts did not stop new protests, which drew attention to issues around the foreignization of land ownership in Corrientes, with HMC as a main target (Cultural Survival, 2014).

Another concern surrounding HMC's investment in Iberá relate to the granting of FSC certification. A platform of environmental NGOs, including Greenpeace and Aves Argentinas, has queried how FSC certification could be granted to a plantation in an area of high ecological value, especially because impacts on local fauna, water balance and soil fertility were evident (Greenpeace et al., 2011; Pittaro, 2011). They demanded the voidance of FSC certification to any plantation inside the Iberá protected area or buffer zone. They also demanded that specific FSC guidelines be developed for wetland habitats, given that the current FSC standards do not specifically address wetland areas.

A further criticism concerns the process of certification. Interviewees denounced how HMC potentially could hide its bad practices during the pre-announced audits and thus manipulate the certification process (see also Oakland Institute, 2013). For example, workers without formal work contracts could be asked to stay at home during the audit. Responsible Harvard and Guardianes del Iberá reported there was a fear of retaliation amongst employees if they would speak up about the poor practices (see also Pittaro, 2011). 
An additional issue surrounding the certification process concerned the limited attention given to social issues in the FSC framework in general (Klooster, 2010; Dare et al., 2011), and especially in the context of Iberá (Hashmi, 2014). A more sensitive approach to socio-cultural diversity in the certification of tree plantations is needed (see Overbeek et al., 2012).

\subsection{Socio-political development in HMC's activities}

The HMC case also revealed some positive outcomes. Certification has the capacity to stimulate companies and public institutions to improve their socio-environmental standards, with HMC and its subsidiaries setting a good example for plantation management in the region. This was especially important in Corrientes where working conditions in the forestry sector were poor. These conditions were exacerbated by the fact that appropriate regulations were not in place to protect workers or prevent misconduct such as unpaid hours, exploitation, informal labour arrangements, etc. Stimulated by its FSC certification, HMC and subsidiaries became involved in a range of social development activities, including: providing transportation for school children; worker safety programs; and dental health initiatives. Furthermore, effort was expended on an employee environmental awareness program regarding garbage management and composting. Land has been set aside for conservation purposes, and there is strict environmental monitoring of the plantations, and reduced use of agrochemicals.

\subsection{Socio-environmental conflict surrounding Tompkins \& CLT}

The Tompkins investments and their presence in the region provide an interesting example of governance within neoliberal conservation. Their activities have influenced the management of various protected areas and have led to contestation and conflict (Saverin, 2014). First, there have been campaigns against the land investments of the Tompkins with the Guardianes del Iberá organized a campaign in 2013 denouncing Tompkins' land transactions as land grabbing (Radio Mundo Real, 2013). Second, the large scale of the Tompkins investments has concentrated land ownership in foreign hands, and has raised questions regarding land sovereignty, especially whether it was desirable to hand over Argentina's say in how land should be used, by who, and for what purpose. Selling this large amount of land to foreigners (150,000 ha) was interpreted by local people and the media as a form of neo-colonialism (Garay, 2004). Critical academic debates associate the foreignization of land with power concentration and constraints on equitable and sustainable development (Zoomers, 2010). Foreign investments might be prioritized, especially where governments seek to attract foreign capital by lowering entry barriers and incentivizing foreign access to land (Corson, 2011; Zoomers, 2010). Summarizing, Tompkins' land investments for conservation have been perceived by Argentinean society with ambiguity. On the one hand, there was scepticism about their intentions; on the other hand, there was admiration for their projects by those locals willing to collaborate with them.

\subsection{Socio-political development in Tompkins \& CLT's activities}

Despite the criticism of Tompkins' conservation projects, it is possible to observe the triggering of positive developments in Iberá. From a social perspective, CLT initiated several projects to reappraise local culture and stimulate sustainable tourism in Iberá. For example, the 'Corrientes vuelve a ser Corrientes' (in English 'Corrientes will be Corrientes again') project played an important role in reinvigorating the cultural, environmental and social elements that characterize Corrientes. 'La Ruta Escénica' (in English 'Scenic Route') project led to the development of new infrastructure and roads opening new access points to the Iberá reserve. Both projects promoted and facilitated local small-scale tourism development. In collaboration with CLT, the provincial government started a project in which conservation and tourism are presented as strategic steps to simultaneously stimulate rural development and conserve nature (Proyecto Iberá, 2016). Even though difficulties were encountered in implementing these projects, awareness of the importance of conserving Iberá was raised and possibilities for local initiatives were identified. However, not all local people have the capacity to start local initiatives, and therefore a significant part of the community might remain excluded (see Corson, 2011). Moreover, for many critical academics (Büscher and Fletcher, 2015; Corson, 2011; Igoe and Brockington, 2007), CLT's activities can be framed as a capital accumulation strategy that commodifies nature.

A program that raised ecological awareness was the reintroduction of locally extinct species, such as the jaguar and giant anteater. Heinonen (2015, author translation), the director of the CLT, perhaps somewhat over-enthusiastically stated that CLT is "working on a project to restore ecosystems and regenerate processes ... that have been disturbed by environmental impacts ... we are writing history in Latin America, no other project like this exists where people are working on the complete restoration of an ecosystem". However, CLT's programs also have contradictions because people value nature in different ways. People living on the fringes of Iberá historically have hunted for survival and leisure. As observed during our fieldwork, hunting continues today (even targeting the very animals being reintroduced), showing how certain local uses of Iberá clash with the ecological values held by CLT. From a governance perspective, situations like this raise questions about ideals, representations, and the sharing of the benefits of nature.

All in all, environmental organizations and philanthropists face various challenges in the implementation of their programs. A longterm commitment is needed to successfully achieve program outcomes that are socially accepted and bring benefits to all actors (Jijelava and Vanclay, 2014). CLT has been very influential in drawing attention to the importance of protecting Iberá. The role of CLT in steering protected areas highlights the positive outcomes foreign land acquisitions can have (see also Zoomers, 2010). This is exemplified in the recent transfer of the land titles from CLT to the Argentinean state for the creation of the National Park Iberá (La Nación, 2015).

\subsection{The complexities of governance in land grabs}

The empirical material has provided a nuanced overview of the many governance dynamics present in protected areas. The two cases show that the effects of land grabbing go further than simply capturing control over land. Land grabs (including green grabs) introduce changes to the entire governance system. However, the arrival of foreign investors is not necessarily the main or only cause of the many social problems or conflicts observed in the deprived rural areas of Iberá. As pointed out by many scholars (Corson, 2011; Dressler and Roth, 2010; Fairhead et al., 2012; Hall et al., 2015), it is important to consider the place-based particularities and histories of each location. The root cause of many problems of local people is arguably not the arrival of the land grabbers, rather it is the reduction of the barriers to investment by governments. With foreign investment bringing in the capital needed by low income provinces (e.g. Corrientes), governments create a regulatory environment that is attractive to investors, but which overlooks the needs and interests of impacted communities. Both cases showed that the entrance of foreign actors facilitated a concentration of land ownership and exacerbated inequalities. However, these inequalities and deprivations have older historical and political roots that stem from the political and social history of Argentina (Slutzky, 2014). In Corrientes, people have historically felt excluded from development and this is expressed in contemporary conflicts (Slutzky, 2014).

Another challenge companies and philanthropists have to deal with is the local setting. Local characteristics create operational challenges for the implementation and operation of investment projects, especially in a complex context like Iberá. These operational challenges include: 
aligning visions; getting people to think about the future; establishing participatory and deliberative processes; resolving pre-existing conflict; and implementing an ongoing and sustainable process of development without entrenching dependency (Esteves and Vanclay, 2009). All in all, this results in a conflictive arena where economic development, the protection of nature, and social development are difficult to align.

The major problems and sources of conflict in Iberá were related to the weak regulatory role of the state at the national and provincial level, which has led to enduring social marginalization. There is a long list of improvements that need to be implemented, including the provision of essential public services - education, health and infrastructure - for remote communities, the implementation of better working conditions, and the eradication of unlawful work practices. The provision of public services by the government is increasingly abandoned under neoliberalism. There is no clear responsibility regarding how local people can be elevated out of their current situation of entrenched poverty.

Civil society groups are another critical component of the system of governance in land grabs. Various groups are active in raising awareness and the appreciation of the values associated with protected areas. They deploy different strategies in the struggle against land grabbing like fostering awareness, denouncing bad practices, and demanding more responsible company behaviour (Hall et al., 2015; Hanna et al., 2016b; Klooster, 2010). One strategy used by these groups to fight for their objectives is forming alliances at multiple levels. In our case studies, it was evident that the demands raised by local groups were rarely fully met. However, the NGOs had some impact, like increasing community awareness of issues and enabling local communities to be better organised and informed. Nevertheless, the spaces of participation are controlled by neoliberal logic, and governments tend to represent economic market interests rather than community interests (Kaika, 2017; Swyngedouw, 2011).

\section{Conclusion: land grabbing and governance changes within protected areas}

The growing presence of business actors and social elites in protected areas creates changing, contradictory and multifaceted meanings for the governance of conservation (Holmes, 2014b). Whereas in the past, conservation tended to mean only the protection of scenic places, species and habitats by public authorities with public finance, now conservation policies allow a wider range of activities, including privately-owned parks, ecotourism, and biodiversity offsets and reserves by forestry companies and other production enterprises. These conservation activities are resisted or supported by local communities and other stakeholders depending on whether the interests, needs and demands of different actors are met, the impacts experienced, and the effectiveness of the engagement processes used (Vanclay, 2017a). Actions to conserve nature are increasingly being undertaken by influential foreign entities. As seen in Iberá, the presence of these actors may not always harm the environment and/or the local people. However, even though there may be attempts by companies to do good, there can always be controversy about their activities.

Land use and ownership changes reinvigorate historical controversies. Even philanthropists and companies with the best intentions cannot avoid dealing with the local history of the places in which they operate. Corrientes and the area surrounding Iberá are characterized by persistent inequality, disunity and socio-political struggle. In such a context, the Harvard Management Company and Douglas Tompkins/ CLT were easy scapegoats for quick judgements about anything that was perceived to be inadequate in Corrientes. The socio-political-historical context is typically not sufficiently analysed or taken into account in project development, including by HMC and CLT. However, sometimes the problems may be so complex that they are inherently unsolvable. As emblematic American actors, HMC and Tompkins have been the subject of a disproportionate level of criticism. Many other operators with much worse practices can be found in Corrientes (and elsewhere), yet they receive less scrutiny.

Even though land grabbing and green grabbing have been criticized in this paper and elsewhere for placing land in the hands of the few and for the many misconducts and mistakes made, they may also open-up spaces for reflecting on the environmental values and social responsibilities of individuals, communities, NGOs, governments and companies. This perspective is not always highlighted. Thus, in the governance of protected areas, there is a need to find a way to bring together the many different perspectives and interests, so that all parties can contribute and benefit.

As demonstrated in our two case studies, land grabbing led to various governance changes having positive and negative outcomes. These changes highlight the failed promises of governance identified by Swyngedouw (2005). First, governance proclaims to create more democratic spaces, whereas in Iberá, poor local people continued to be excluded and expelled. Second, land grabs are presented by governments and investors as bringing opportunities for local people, while in reality the land grabs pose a threat to local people's livelihoods and may lead to environmental degradation. Third, neoliberal conservation promises greater transparency, whereas the involvement of more and varying actors across scales increases the blurriness about accountability, roles and responsibilities.

These three points highlight that governance of protected areas is dynamic, multifaceted, complex, and does not serve the interests of all actors. The belief that neoliberal conservation can bring sustainability (Corbera, 2015; Costello et al., 2012) while continuing to allow exploitative practices (Cook and Swyngedouw, 2012) is manifestly invalid, especially in the Latin American countries where neoliberalism is much promoted (Parra and Moulaert, 2016; Veltmeyer and Petras, 2014). As argued by Overbeek et al. (2012), local people are disadvantaged because of the absence of the state from key social responsibilities such as education and health. Moreover, governments support the very industries that are destroying the environment and livelihoods of local communities. If no emphasis is given to enabling local people to maintain control over land, rural-to-urban migration will inevitably occur, leading to people entering the ranks of the urban poor (Fairhead et al., 2012; Gerber, 2011). These issues promote civil resistance and reduce the stability of government (Veltmeyer and Petras, 2014).

Protected areas are subject to both green grabbing and land grabbing. Regardless of the term, the impacts experienced are similar in that local people are displaced or have their use of land and resources restricted, their environments are harmed such that maintaining their livelihoods becomes impossible, and/or they experience considerable other social impacts and upheaval. In this sense, green grabbing can be seen as a type of extractivism. From the positioning of local people, green grabbing is land grabbing. Facilitating the ability of local people to gain formal land title, increasing awareness of land grabbing issues, increasing the scrutiny of land investors by all stakeholders, and increasing the opportunities for local people would go a long way to enhance the benefits and mitigate the harms from land grabbing.

\section{Acknowledgements}

The fieldwork was supported by the Erasmus Mundus program of the European Union 'Excellence Scholarship for Latin Americans and Europeans'. The Research Fund of KU Leuven also supported this article through STG 14/022. We would like to thank The Conservation Land Trust/Proyecto Iberá for granting permission to use their map of Los Esteros del Iberá. We would also like to thank the anonymous reviewers for their valuable feedback on the paper. Finally, we would like to thank the people who participated in the research by sharing their experiences. 


\section{References}

Aranda, D., 2015. Tierra Arrasada: Petróleo, soja, pasteras y megaminería radiografía de la Argentina del siglo XXI. Sudamericana, Buenos Aires.

Baird, I.G., 2011. Turning land into capital, turning people into labour: primitive accumulation and the arrival of large-scale economic land concessions in the Lao People's Democratic Republic. N. Proposals J. Marx. Interdiscip. Inq. 5 (1), 10-26.

Bayard, G.H., Wohns, S.F., 2014. The Harvard Crimson: A Steep Price for Harvard's Investments (Last Accessed 21 September 2017) on:. http://www.thecrimson.com/ article/2014/4/9/steep-price-investment/.

Bidaseca, K., Gigena, A., Gómez, F., Weinstock, A.M., Oyharzábal, E., Otal, D., 2013. Relevamiento y sistematización de problemas de tierras de los agricultores familiares en Argentina. Ministerio de la Agricultura, Ganadería y Pesca de la Nación, Buenos Aires.

Boletín de los Esteros, 2010. Iberá en Peligro. Edición Especial, Número 8. [Last Accessed 21 September 2017 on: http://cltargentina.org/download/boletines/boletin_08.pdf].

Borras, S.M., Kay, C., Gómez, S., Wilkinson, J., 2012a. Land grabbing and global capitalist accumulation: key features in Latin America. Can. J. Dev. Stud. 33 (4), 402-416.

Borras, S.M., Franco, J., Gómez, S., Kay, C., Spoor, M., 2012b. Land grabbing in Latin America and the Caribbean. J. Peasant Stud. 39 (3-4), 845-872.

Borras, S.M., Franco, J., Wang, C., 2013. The challenge of global governance of land grabbing: changing international agricultural context and competing political views and strategies. Globalizations 10 (1), 161-179.

Borras, S.M., Franco, J., Isakson, S., Levidow, L., Ververst, P., 2016. The rise of flex crops and commodities: implications for research. J. Peasant Stud. 43 (1), 93-115.

Brent, Z., 2015. Territorial restructuring and resistance in Argentina. J. Peasant Stud. 42 (3-4), 671-694.

Brockington, D., Igoe, J., 2006. Eviction for conservation: a global overview. Conserv. Soc. 4 (3), 424-470.

Brockington, D., Duffy, R., Igoe, J., 2008. Nature Unbound: Conservation, Capitalism, and the Future of Protected Areas. Earthscan, London.

Büscher, B., Fletcher, R., 2015. Accumulation by conservation. N. Polit. Econ. 20 (2), 279-298.

Büscher, B., Sullivan, S., Neves, K., Igoe, J., Brockington, D., 2012. Towards a synthesized critique of neoliberal biodiversity conservation. Capitalism Nat. Social. 23, 24-30.

Business Wire, 2014. Harvard Management Company's Argentine Timberland Plantations Receive FSC ${ }^{\circledast}$ Certification (Last Accessed 21 September 2017) on:. http://www. businesswire.com/news/home/20140407006112/en/Harvard-ManagementCompany\%E2\%80\%99s-Argentine-Timberland-Plantations-Receive.

Castree, N., 2010. neoliberalism and the biophysical environment 1: what' neoliberalism' is, and what difference nature makes to it. Geogr. Compass 4 (12), 1725-1733.

Castree, N., Henderson, G., 2014. The capitalist mode of conservation, neoliberalism and the ecology of value. N. Proposals J. Marx. Interdiscip. Inq. 7 (1), 16-37.

Cavanagh, C., Benjaminsen, T.A., 2014. Virtual nature, violent accumulation: the 'spec tacular failure' of carbon offsetting at a Ugandan National Park. Geoforum 56, 55-65.

CLT, 2016. The Conservation Land Trust (Last Accessed 21 September 2017) on:. http:// www.theconservationlandtrust.org/eng/ibera.htm.

Cook, I.R., Swyngedouw, E., 2012. Cities, social cohesion and the environment: towards a future research agenda. Urban Stud. 49, 1959-1978.

Corbera, E., 2015. Valuing nature, paying for ecosystem services and realizing social justice: a response to Matulis (2014). Ecol. Econ. 110, 154-157.

Corson, C., 2011. Territorialization, enclosure and neoliberalism: non-state influence in struggles over Madagascar's forests. J. Peasant Stud. 38 (4), 703-726.

Corson, C., MacDonald, K.I., 2012. Enclosing the global commons: the convention on biological diversity and green grabbing. J. Peasant Stud. 39 (2), 263-283.

Corson, C., MacDonald, K.I., Neimark, B., 2013. Grabbing "Green": markets, environmental governance, and the materialization of natural capital. Hum. Geogr. 6 (1), $1-15$.

Costantino, A., 2015. El capital extranjero y el acaparamiento de tierras: conflictos sociales y acumulación por desposesión en Argentina. Revista de Estudios Sociales 55, $137-149$

Costantino, A., 2016. The dark side of the boom: Land grabbing in dependent countries in the twenty-first century. Int. Crit. Thought 6 (1), 79-100.

Costello, C., Gaines, S., Gerber, L.R., 2012. Conservation science: a market approach to saving the whales. Nature 481 (7380), 139-140.

Cotula, L., Vermeulen, S., Leonard, R., Keeley, J., 2009. Land Grab or Development Opportunity? Agricultural Investment and International Land Deals in Africa, London/Rome IIED/FAO/IFAD.

Cultural Survival, 2014. Argentina: Communities Protest Foreign Land Grabs in Ibera (Last Accessed 21 September 2017) on:. https://www.culturalsurvival.org/news/ argentina-communities-protest-foreign-land-grabs-ibera.

Cundill, G., Thondhlana, G., Sisitka, L., Shackleton, S., Blore, M., 2013. Land claims and the pursuit of co-management on four protected areas in South Africa. Land Use Policy $35,171-178$

Dare, M., Schirmer, J., Vanclay, F., 2011. Does forest certification enhance community engagement in Australian plantation management? For. Policy Econ. 13 (5), 328-337.

Davis, K., D’Odorico, P., Rulli, M., 2014. Land grabbing: a preliminary quantification of economic impacts on rural livelihoods. Popul. Environ. 36, 180-192.

de Schutter, O., 2011. How not to think of land-grabbing: Three critiques of large-scale investments in farmland. J. Peasant Stud. 38 (2), 249-279.

Dressler, W., Roth, R., 2010. The Good, the Bad, and the Contradictory: neoliberal conservation governance in rural Southeast Asia. World Dev. 39 (5), 851-862.

Edelman, M., Oya, C., Borras, S.M., 2013. Global Land Grabs: historical processes, theoretical and methodological implications and current trajectories. Third World Q. 34
(9), 1517-1531.

Eden, S., 2009. The work of environmental governance networks: traceability, credibility and certification by the Forest stewardship council. Geoforum 40, 383-394.

El Diario Digital, 2007. Tompkins habría demolido una escuela en el Iberá (Last Accessed 21 September 2017) on:. http://www.voxpopuli.com.ar/archivo/2007/mayo/ misiones2007051405.shtml.

El Litoral, 2006a. Goya: el obispo no aceptó trabajar con Tompkins (Last Accessed 21 September 2017) on:. http://www.ellitoral.com.ar/34448/Goya-el-Obispo-noaceptotrabajar-con-Tompkins.

El Litoral, 2006b. Tompkins donará parte de sus terrenos para construir un acceso a Yahaveré (Last Accessed 21 September 2017) on:. http://www.ellitoral.com.ar/ 46233/Tompkins-donara-parte-de-sus-terrenos-para-construir-un-acceso-a-Yahavere.

Esteves, A.M., Vanclay, F., 2009. Social development needs analysis as a tool for SIA to guide corporate-community investment: applications in the minerals industry. Environ. Impact Assess. Rev. 29 (2), 137-145.

Fairhead, J., Leach, M., Scoones, I., 2012. Green grabbing: a new appropriation of nature? J. Peasant Stud. 39 (2), 237-261.

Fleming, A., Vanclay, F., Hiller, C., Wilson, S., 2014. Challenging conflicting discourses of climate change. Clim. Change 127 (3-4), 407-418.

Food and Agriculture Organization of the United Nations, 2012. Voluntary Guidelines on the Responsible Governance of Tenure of Lands, Fisheries and Forests in the Context of National Food Security (Last Accessed 21 September 2017) on:. http://www.fao. org/docrep/016/i2801e/i2801e.pdf.

Forest Stewardship Council, 2015. FSC Principles and Criteria for Forest Stewardship. FSC-STD-01-001 V5-2 EN (Last Accessed 21 September 2017) on:. FSC International Standard. https://ic.fsc.org/preview.fsc-principles-and-criteria-for-foreststewardship-fsc-std-01-001-v5-2-en-print-version.a-4843.pdf.

Fortin, E., Richardson, B., 2013. Certification schemes and the governance of land: enforcing standards or enabling scrutiny? Globalizations 10 (1), 141-159.

Garay, F., 2004. Esteros del Iberá: Douglas Tomkins (sic), el dueño de la polémica (Last Accessed 21 September 2017) on:. http://www.rodolfowalsh.org/spip.php? breve1353.

Gerber, J.F., 2011. Conflicts over industrial tree plantations in the South: who, how and why? Global Environ. Change 21, 165-176.

Gerber, J.F., Veuthey, S., Martínez-Alier, J., 2009. Linking political ecology with ecological economics in tree plantations conflicts in Cameroon and Ecuador. Ecol. Econ. 68, 2885-2889.

Giardinelli, M., 2015. Douglas Tompkins in Memoriam (Last Accessed 21 September 2017) on:. http://www.pagina12.com.ar/diario/sociedad/3-288218-2015-12-14. html.

Gobierno Provincial, 2015. Fondos nacionales para el NEA: Corrientes recibió hasta 300\% menos que el resto (Last Accessed 21 September 2017) on:. http://www.corrientes. gov.ar/noticia/fondos-nacionales-para-el-nea-corrientes-recibio-hasta-300-menosque-el-resto.

Gobierno Provincial Corrientes, 2015. Parque Provincial Iberá. Producción de naturaleza y desarrollo local. Gobierno Provincial Corrientes, Corrientes.

Goldfarb, L., van der Haar, G., 2015. The moving frontiers of genetically modified soy production: shifts in land control in the Argentinian chaco. J. Peasant Stud. 43 (2), $562-582$.

Grajales, A., 2011. The rifle and the title: paramilitary violence, land grab and land control in Colombia. J. Peasant Stud. 38 (4), 771-791.

Greenpeace, Aves Argentinas, Fundación Biodiversidad, Fundación Flora y Fauna Argentina, Delegación Técnica Regional Noreste Argentino Administración de Parques Nacionales, IABIN Red Interamericana de Información sobre Biodiversidad, 2011. La inclusión de pastizales de Alto Valor de Conservación dentro de la Agenda del FSC. Un cambio importante y urgente dentro del contexto ambiental mundial. El caso de la región del Iberá en Corrientes, Argentina. [Last Accessed 21 September 2017 on: http://www.greenpeace.org/argentina/Global/argentina/report/2011/ bosques/inclusion-pastizales-fsc.pdf]

Gudynas, E., 2009. Diez tesis urgentes sobre el nuevo extractivismo - Contextos y demandas bajo el progresismo sudamericano actual. In: Schuldt, J., Acosta, A., Barandiarán, A., Bebbington, A., Folch, M., CEDLA, Alayza, A., Gudynas, E. (Eds.), Extractivismo, Política y Sociedad. CLAES CAAP, Quito, pp. 187-225.

Hábitat y Desarrollo Fundación, 2014. Iberá, Los Caminos del Agua: Guía de Naturaleza (Last Accessed 21 September 2017) on:. https://issuu.com/ fundacionhabitatydesarrollo/docs/cuadernillo ibera.

Hall, R., Edelman, M., Borras, S.M., Scoones, I., White, B., Wolford, W., 2015. Resistance, acquiescence or incorporation? An introduction to land grabbing and political reac tions 'from below'. J. Peasant Stud. 42 (3-4), 467-488.

Hanna, K., Clark, D., Slocombe, D. (Eds.), 2008. Transforming Parks and Protected Areas: Policy and Governance in a Changing World. Routledge, London.

Hanna, P., Vanclay, F., Langdon, E.J., Arts, J., 2014. Improving the effectiveness of impact assessment pertaining to indigenous peoples in the Brazilian environmental licensing procedure. Environ. Impact Assess. Rev. 46, 58-67.

Hanna, P., Langdon, J., Vanclay, F., 2016a. Indigenous rights, performativity and protest. Land Use Policy 50, 490-506.

Hanna, P., Vanclay, F., Langdon, E.J., Arts, J., 2016b. Conceptualizing social protest and the significance of protest action to large projects. Extr. Ind. Soc. 3 (1), 217-239.

Harvard Gazette, 2014. Harvard to Sign on to United Nations-Supported Principles for Responsible Investment (Last Accessed 21 September 2017) on:. http://news. harvard.edu/gazette/story/2014/04/harvard-to-sign-on-to-united-nationssupported-principles-for-responsible-investment/.

Harvard Management Company, 2018. (Last Accessed 19 March 2018) on: http://www. hmc.harvard.edu/.

Harvey, D., 2005. A Brief History of Neoliberalism. Oxford University Press, Oxford UK. Hashmi, A.H., 2014. With Argentine Timberlands Recertified, Local Organizers Lodge 
Complaints (Last Accessed 21 September 2017) on:. The Harvard Crimson. http:// www.thecrimson.com/article/2014/4/7/harvard-argentine-timberlandsrecertified/.

Heinonen, S., 2015. Public press event: Anuncian el desarrollo de una gran área protegida en Los Esteros del Iberá (Last Accessed 21 September 2017) on:. Hostnews Diario de Turismo. https://www.youtube.com/watch?v= NJJRjKhQkVo.

Holmén, H., 2015. Is land grabbing always what it is supposed to be? Large-scale land investments in sub-Saharan Africa. Dev. Policy Rev. 33 (4), 457-478.

Holmes, G., 2014a. What is a land grab? Exploring green grabs, conservation and private protected areas in Southern Chile. J. Peasant Stud. 41 (4), 547-567.

Holmes, G., 2014b. Defining the forest, defending the forest: political ecology, territoriality, and resistance to a protected area in the Dominican Republic. Geoforum 53, $1-10$.

Holmes, G., Cavanagh, C., 2016. A review of the social impacts of neoliberal conservation: formations, inequalities, contestations. Geoforum 75, 199-209.

Hoyle, S., 2014. Good for Harvard Good for the World: Why HMC Embraced ESG With a Passion (Last Accessed 21 September 2017) on:. https://www.top1000funds.com/ profile/2014/10/28/good-for-the-world-why-harvard-has-embraced-esg-with-apassion/.

Igoe, J., Brockington, D., 2007. Neoliberal conservation: a brief introduction. Conserv. Soc. 5 (4), 432-449.

Jara, C., Paz, R., 2013. Ordenar el territorio para detener el acaparamiento mundial de tierras. La conflictividad de la estructura agraria de Santiago del Estero y el papel del estado, vol. 15. Proyección, pp. 171-195.

Jijelava, D., Vanclay, F., 2014. Assessing the social licence to operate of the work of humanitarian and development cooperation organizations: a case study of mercy corps in samtskhe-javakheti, Georgia. Soc. Epistemol. 28 (3-4), 297-317.

Jones, N., McGinlay, J., Dimitrakopoulos, P., 2017. Improving social impact assessment of protected areas: a review of the literature and directions for future research. Environ. Impact Assess. Rev. 64, 1-7.

Kaika, M., 2017. Don't call me resilient again!” The New Urban Agenda as immunology ... or what happens when communities refuse to be vaccinated with 'smart cities' and indicators. Environ. Urban 29 (1), 89-102.

Klooster, D., 2010. Standardizing sustainable development? The Forest Stewardship council's plantation policy review process as neoliberal environmental governance. Geoforum 41, 117-129.

La Nación, 2015. Mauricio Macri recibió a la viuda de Douglas Tompkins para agradecerle por una donación de tierras (Last Accessed 21 September 2017) on:. http://www. lanacion.com.ar/1856473-mauricio-macri-recibio-a-la-viuda-de-douglas-tompkinspara-agradecerle-por-una-donacion-de-tierras.

La Política Online, 2011. Tompkins vende tierra a extranjeros en los Esteros del Iberá (Last Accessed 21 September 2017) on:. http://www.lapoliticaonline.com/nota/ 51023/.

Leguizamón, A., 2016. Environmental injustice in Argentina: struggles against genetically modified soy. J. Agrar. Change 16 (4), 684-692.

Loiselle, S.A., Bastianoni, S., Bracchini, L., Rossi, C., 2004. Neotropical wetlands: New instruments in ecosystem management. Wetlands Ecol. Manage. 12, 587-596.

Lunstrum, E., Bose, P., Zalik, A., 2016. Environmental displacement: the common ground of climate change, extraction and conservation. Area 48 (2), 130-133.

Margulis, M.E., McKeon, N., Borras, S.M., 2013. Land grabbing and global governance: critical perspectives. Globalizations 10 (1), 1-23.

Messerli, P., Heinimann, A., Giger, M., Breu, T., Schönweger, O., 2013. From 'land grabbing' to sustainable investments in land: potential contribution by land change science. Curr. Opin. Environ. Sustain. 5, 528-534.

Mi Mercedes, 2007. Paraje Yahavere: Ahora alambran el agua (Last Accessed 21 September 2017) on:. http://www.mimercedes.com.ar/masnotas.php?ampliar= 6924.

Ministerio de Justicia y Derechos Humanos, 2017. Dirección Nacional del Registro Nacional de Tierras Rurales, Cartografía (Last Accessed 21 September 2017) on:. http://www.jus.gob.ar/tierras-rurales/cartografia.aspx.

Minteer, B.A., Pyne, S.J. (Eds.), 2015. After Preservation: Saving American Nature in the Age of Humans. University of Chicago Press, Chicago.

Moulaert, F., Parra, C., Swyngedouw, E., 2014. Cities, neighbourhoods and multiscalar governance in urban Europe. EURE. Revista latinoamericana de estudios urbano regionales 40 (119), 5-24.

Murmis, M., Murmis, M.R., 2012. Land concentration and foreign land ownership in Argentina in the context of global land grabbing. Can. J. Dev. Stud. 33 (4), 490-508.

Neiff, J.J., 2004. El Iberá ¿En Peligro? Fundación Vida Silvestre Argentina, Buenos Aires.

Oakland Institute, Responsible Investment at Harvard Coalition, 2013. Harvard In Iberá. Investigating Harvard University's Timber Plantations in the Iberá Wetlands of Argentina. Oakland New York, USA. [Last accessed 21 September 2017 on: https:// www.oaklandinstitute.org/sites/oaklandinstitute.org/files/OI_Report_Harvard_Ibera_ 0.pdf].

Oliveira, G., Hecht, S., 2016. Sacred groves, sacrifice zones and soy production: globalization, intensification and neo-nature in South America. J. Peasant Stud. 42 (2), 251-285.

Overbeek, W., Kröger, M., Gerber, J.F., 2012. An Overview of Industrial Tree Plantations Conflicts in the Global South: Conflicts, Trends, and Resistance Struggles. EJOLT Report No. 3. 100p. (Last Accessed 21 September 2017) on:. . http://www.ejolt.
org/wordpress/wp-content/uploads/2012/06/EJOLT-Report-3-low1.pdf.

Parra, C., 2010. Sustainability and multi-level governance of territories classified as protected areas in France: the Morvan Regional Park case. J. Environ. Plann. Manage. 53 (4), 491-509.

Parra, C., Moulaert, F., 2016. The governance of the nature-culture nexus: lessons learned from the San Pedro de Atacama case-study. Nat. Cult. 11 (3), 239-258.

Partido Comunista Revolucionario de la Argentina, 2014. Tierra y soberanía (Last Accessed 21 September 2017) on:. Histórico triunfo de la Unión Campesina de Corrientes. http://www.pcr.org.ar/nota/campo/tierra-y-soberan\%C3\%AD.

Pittaro, F., 2011. Harvard: la universidad tiene campos en Corrientes e incumple con la ley. Tiempo Argentino. (Last Accessed 21 September 2017) on:. https:// fabaexpresbiz.files.wordpress.com/2011/11/68369915-harvard.pdf.

PRI, 2016. Principles for Responsible Investment. The Six Principles (Last Accessed 21 September 2017) on:. http://www.unpri.org/about-pri/the-six-principles/.

Provincia de Corrientes, 2014. Educar para un desarrollo forestoindustrial sustentable. Imprenta La Stampa, Buenos Aires.

Proyecto Iberá, 2016. [Last Accessed 21 September 2017 on: http://www.proyectoibera. org/].

Radio Mundo Real, 2013. La otra cara de la moneda (Last Accessed 21 September 2017) on:. diálogo con Emilio Espataro de la organización' Guardianes del Iberá', Argentina. http://www.radiomundoreal.fm/6897-la-otra-cara-de-la-moneda?lang = es.

Rocheleau, D.E., 2015. Networked, rooted and territorial: Green grabbing and resistance in Chiapas. J. Peasant Stud. 42 (3-4), 695-723.

Ruta de Arroz, 2011. Una millionaria francesa se adueñó de un curso de agua en Corrientes (Last Accessed 21 September 2017) on:. http://www.rutadearroz.com/ noticias/val/2385/val_s/95/una-millonaria-francesa-se-adue\%F1\%F3-de-un-cursode-agua-en-corrientes.html.

Saverin, D., 2014. The entrepreneur who want to save paradise. The Atlantic. (Last Accessed 21 September 2017) on: https://www.theatlantic.com/business/archive/ 2014/09/the-entrepreneur-who-wants-to-save-paradise/380116/.

Sili, M., Soumoulou, L., 2011. The Issue of Land in Argentina: Conflicts and Dynamics of Use, Holdings and Concentration (Last Accessed 21 September 2017) on:. The International Fund for Agricultural Development. https://www.ifad.org/documents/ 10180/e2364b6f-036e-46e3-b611-1dadfa951ad5.

Silva, C., Boia, C., Valente, J., Borrego, C., 2005. Pesticides in Esteros del Ibera (AR): evaluation of impacts and proposal of guidelines for water quality protection. Ecol. Modell. 186, 85-97.

Slutzky, D., 2014. Estructura social agraria y agroindustria del Nordeste de la Argentina: desde la incorporación a la economía nacional al actual subdesarrollo concentrador y excluyente. Editorial Universitaria, Universidad Nacional de Misiones, Misiones.

Stolton, S., Dudley, N. (Eds.), 2010. Arguments for Protected Areas: Multiple Benefits for Conservation and Use. Earthscan, London.

Svampa, M., Viale, E., 2014. Maldesarrollo: La Argentina del extractivismo y el despojo. Katz Editores, Buenos Aires.

Swyngedouw, E., 2005. Governance innovation and the citizens: the Janus face of governance-beyond-the-state. Urban Stud. 42 (11), 1991-2006.

Swyngedouw, E., 2011. Interrogating post-democratization: reclaiming egalitarian political spaces. Polit. Geogr. 30, 370-380.

Temper, L., 2018. From boomerangs to minefields and catapults: dynamics of trans-local resistance to land-grabs. J. Peasant Stud. 1-29. https://doi.org/10.1080/03066150. 2017.1398144.

Tompkins Conservation, 2017. [Last Accessed 21 September 2017 on: http://www. tompkinsconservation.org/milestones.htm].

Tujcheider, O., Perez, M., Paris, M., D’Elia, M., 2007. The Guaraní Aquifer System: stateof-the-art in Argentina. In: Chery, L., de Marsily, G. (Eds.), Aquifer Systems Management. Darcy's Legacy in a World of Impending Water shortage, 239-252. Taylor \& Francis, Abingdon.

United Nations, 1992. Convention on Biological Diversity (Last Accessed 21 September 2017) on:. https://www.cbd.int/doc/legal/cbd-en.pdf.

Vanclay, F., 2017a. Principles to assist in gaining a social licence to operate for green initiatives and biodiversity projects. Curr. Opin. Environ. Sustain. 29, 48-56.

Vanclay, F., 2017b. Project induced displacement and resettlement: from impoverishment risks to an opportunity for development? Impact Assess. Project Apprais. 35 (1), $3-21$.

Vanclay, F., Baines, J., Taylor, C.N., 2013. Principles for ethical research involving humans: ethical professional practice in impact assessment part I. Impact Assess. Project Apprais. 31 (4), 243-253.

Veltmeyer, H., Petras, J. (Eds.), 2014. The New Extractivism: A Post-Neoliberal Development Model or Imperialism of the Twenty-First Century? Zed Books, London.

Vidal, J., 2008. The great green land grab. The Guardian. (Last Accessed 21 September 2017) on: http://www.theguardian.com/environment/2008/feb/13/conservation.

World Bank, 2010. The Invisible Poor: A Portrait of Rural Poverty in Argentina. The World Bank, Washington DC.

Zalba, S.M., 2010. Pinos invasores en Iberá: La amenanza silenciosa. Boletín de los Esteros "Iberá en Peligro". Edición Especial, Número 8, 3-7.

Zammit, C., 2013. Landowners and conservation markets: social benefits from two Australian government programs. Land Use Policy 31, 11-16.

Zoomers, A., 2010. Globalization and the foreignization of space: the seven processes driving the current global land grab. J. Peasant Stud. 37 (2), 429-447. 